\title{
Analysis of the impact of tourism e-commerce on the development of China's tourism industry
}

\author{
Meng Ying \\ Marketing College of Business, Xi’an International University, Xi’an, Shaanxi, China, 710077
}

Keywords: tourism; national economy; E-commerce

\begin{abstract}
: tourism as an important industry in the development of the national economy, the effect is good or bad for the development of regional economy and even the national economy is huge, "adjust the structure effects of promoting growth" policy and idea, also is of great significance to promote the tourism development. With the rapid development of e-commerce in recent years, the relationship between it and tourism has become more and more close, and tourism e-commerce has also had a profound impact on the development of tourism. This article will analyze the impact of tourism e-commerce on the development of domestic tourism, and propose reasonable suggestions on how to promote the development of tourism e-commerce in order to better influence the development of tourism.
\end{abstract}

\section{Introduction}

Tourism e-commerce is a relatively new form of e-commerce, and tourism, as a typical service industry, is essential to maintain high speed and high quality in its development. More and more people have realized the impact of tourism e-commerce on the development of tourism, and tourism e-commerce has also been a certain dissemination and development. But it is not difficult to see that the positive impact of tourism e-commerce on the development of China's tourism industry at this stage is relatively limited, and the overall development of the tourism industry also presents the situation of insufficient stamina. In the new period, it is very important to promote the development of the domestic tourism industry, and it is also a better choice to promote the development of the tourism industry with the help of tourism e-commerce.

\section{Overview of tourism e-commerce}

Tourism e-commerce is to improve the Tourism Institutions of internal and external connectivity by means of advanced information technology, which makes the relationship between tourism enterprises more closely, information communication more smoothly, a kind of electronic commerce form the relationship between tourism enterprises and tourists. From the essence of tourism e-commerce, it is actually a product of the development of e-commerce to a certain extent, and tourism e-commerce is also a manifestation of the integration of e-commerce and tourism development. Thanks to the current domestic Internet environment is good and the electronic commerce has been widely recognized, the development of tourism e-commerce environment has a variety of effects of tourism e-commerce development of the tourism industry more gradually. From the current situation of the development of tourism, e-commerce has been a good development, but the positive impact of tourism e-commerce development of the tourism industry is still limited, the domestic tourism industry also did not make full use of the tourism e-commerce[1].

\section{The impact of tourism e-commerce on the development of Tourism}

Tourism e-commerce has greatly enriched the domestic tourism development direction, and in the development of tourism e-commerce speed up, the domestic tourism industry also ushered in many opportunities. In view of the past development mode of domestic tourism industry, the consumption of tourism resources is more obvious, and the direction of tourism development is 
very unitary and solidified. Before the emergence of tourism e-commerce, the development of domestic tourism has shown the specific problems of high input and low output, and the vitality of the tourism industry is constantly losing. The development mode of tourism e-commerce and the rapid development has greatly changed the tourism industry, such as B2B, B2E and other forms of tourism e-commerce expands the actual impact of the tourism industry, the tourism industry in the development environment has been well improved. More importantly, tourism e-commerce provides a convenient condition for many tourism enterprises to better participate in the development of tourism, and this can also have a better impact on the development of tourism[2].

The development of tourism e-commerce has greatly enhanced the competitiveness of the tourism industry, especially comparing development of tourism in the domestic tourism development with neighboring countries can be found, the comprehensive competitiveness of domestic tourism is growing, many tourists evaluation of domestic tourism industry team is more and more high. The comprehensive competitiveness of the domestic tourism industry is relatively low for a long time, and the competitiveness of the tourism industry is more difficult to upgrade. The emergence of tourism e-commerce is undoubtedly a phased innovation in the development of the domestic tourism industry, and tourism e-commerce is also an organic link between tourist attractions, tourism enterprises and tourists. At this stage, with greater relevance of tourism development and tourism industry environment, better development of tourism e-commerce, tourism industry to optimize the industrial environment, the development of the tourism industry in some areas is the formation of a supply chain consisting of the supply network, which in fact is also in no shape to promote the tourism industry competitiveness.

The impact of tourism e-commerce in tourism industry is also reflected in the impact of tourism consumption and growth pattern, tourism development, tourism consumption is very important, relying on tourism consumption promote the development of tourism is the best choice. E-commerce was initially a new form in the field of consumption, and tourism e-commerce is actually an external manifestation of tourism consumption. With the rapid development of tourism e-commerce, many tourists consumption patterns and consumer attitudes have changed, tourism consumption is not in the mere cash consumption and face-to-face transactions, e-commerce in the form of tourism e-commerce is the breakthrough time and space constraints, but also makes the tourism consumption more convenient. In the tourism electronic commerce has changed the situation better mode of tourism, domestic tourism growth has quietly changed, the entity over reliance on tourism resources to promote the growth of tourism industry has been expanded, the actual choice of tourism economic growth has also been enriched and expanded[3].

\section{Restricting the positive impact of tourism e-commerce factors}

At this stage, the primary factors restricting tourism e-commerce play a positive effect is the tourism e-commerce attention degree is low, many local governments although the development of the tourism industry pays more attention to it, but the development of its tourism industry is relatively backward, in the development of tourism planning is ignoring the important function of tourism e-commerce. From the point of view of tourism enterprises, the development of tourism e-commerce has not been widely supported by tourism enterprises, which also makes the impact of tourism e-commerce on tourism development very limited. Tourism is a highly market-oriented industry, and in the overall development of tourism, the actual impact and role of tourism enterprises should not be underestimated. In many small and medium-sized tourism enterprises do not attach importance to the development of tourism e-commerce, the tourism e-commerce can not make due contribution to the development of domestic tourism. In the case of some tourism enterprises developing e-commerce in tourism, the tourism e-commerce will have a negative impact on the development of tourism[4].

Tourism e-commerce as a new situation for the development of electronic commerce, it needs good innovation, but the tourism electronic commerce development innovation ability is poor, the lack of awareness of innovation under the guidance of good innovation cannot travel e-commerce. Tourism e-commerce is not relying on the Internet for simple travel transactions or stimulate 
tourism consumption, tourism e-commerce positive impact on tourism development is reflected in many dimensions, tourism e-commerce overall innovative driving force is obviously insufficient, the actual effectiveness of tourism e-commerce is weakening, the use of mechanical part of the tourism business of tourism the electronic commerce also can lead to its development. The innovation of tourism e-commerce is mostly an innovation form, which also led to a lot of tourism e-commerce website is similar in layout, the lack of the actual content of tourism e-commerce support makes tourism e-commerce form feeling is too strong, the actual utility of natural weakening and even loss.

Tourism e-commerce is a relatively new form of e-commerce, and there is a shortage of professionals in the field of tourism e-commerce, and it can not play a role in promoting tourism. In the domestic higher education stage, talent training has not made good integration between tourism and e-commerce. Many graduates of tourism major do not have the ability to develop tourism e-commerce. Electronic commerce professional tourism under the background of the overall demand, the quality of tourism electronic commerce development is relatively low, the tourism e-commerce not only better innovation, with the development of the tourism industry is also easy to separate contact. There are many reasons for the shortage of tourist e-commerce talents, and the fundamental solution to this problem is a longer period of time. In the low development level of tourism industry in some areas, tourism e-commerce talent shortage is very serious, which also makes the tourism e-commerce development level is extremely limited, tourism e-commerce to become a realistic choice for the development of the tourism industry to enhance the level of.

The low service of tourism e-commerce is also one of the problems in the development process of tourism e-commerce, and the service of tourism e-commerce is low, and it can not have a positive impact on tourism development. Tourism itself is a kind of service industry. The purpose of traveling is mostly to relax and delight in mind and body. Tourism e-commerce should become a tourist can be a good use of tools, but the tourism e-commerce in the development of the over emphasis on the profit is very easy to cause the loss of its service attributes, once the lack of tourism e-commerce service better, it cannot be widely accepted for tourists. Tourism e-commerce service many tourism enterprises and tourist attractions provided is not perfect, it also makes the tourism e-commerce internal component effective connection cannot be reached between, the tourism e-commerce not only become better managers of tourism resource management tools, more easily lead to the tourism development speed is very slow[5].

\section{To accelerate the development of tourism e-commerce proposals}

Accelerating the development of tourism e-commerce can better promote the development of tourism, and promote the importance of tourism e-commerce development is also very necessary. As a macroeconomic regulator, the domestic government needs to make a good plan for the development of tourism and the development of tourism e-commerce. The local government needs to rethink the development of tourism e-commerce with the current status of tourism e-commerce and tourism development, and pay more attention to the link between tourism e-commerce and tourism development. Some of the tourism economy accounts for a large area, and the local government needs to encourage the regional tourism enterprises to develop the tourism e-commerce, so that the number of the main part of the development of tourism e-commerce has increased significantly. For tourism enterprises, enterprises need to adapt to the situation of tourism e-commerce development, the introduction of tourism e-commerce development model on the basis of the increased development of tourism e-commerce investment, integrate their own resources of tourism e-commerce development.

It is necessary to make great efforts to carry out innovation in the development of tourism e-commerce, and the positive impact of tourism e-commerce on the tourism industry can be brought into full play under the innovation of tourism e-commerce. Tourism e-commerce innovation needs as a normalization, a variety of specific types of electronic commerce the diversity of tourism e-commerce is not confined to the B2B and B2E of the two basic form, will be more novel B2C, $\mathrm{C} 2 \mathrm{C}, \mathrm{O} 2 \mathrm{O}$ and other forms of electronic commerce is introduced and applied to the development of 
tourism e-commerce is also very necessary. In addition, the innovation of tourism e-commerce should integrate the innovation in form with the innovation in content, so as to avoid the innovation of tourism e-commerce. Suggestions for local government and tourism related enterprises combined with the regional tourism industry development and the characteristics of the tourism resources with a choice of innovation, makes the tourism electronic commerce and tourism resources complement each other, in the tourism electronic commerce has obvious characteristics, tourism e-commerce innovation itself can also upgrade[6].

The development of tourism e-commerce has a high dependence on professionals, and the training and introduction of tourism e-commerce talents can not only promote the development of tourism e-commerce, but also better promote the overall development of tourism industry. The training of domestic tourism professionals should pay attention to the change and adjustment of the demand side of talents, and it will be an educational development trend to integrate tourism management personnel education with tourism e-commerce. In the promotion of tourism development, local governments and tourism enterprises should pay attention to the cultivation and introduction of tourism e-commerce talents, and take talent strategy as an effective strategy for better development of tourism e-commerce. Tourism enterprises need good talent reserves before the tourism e-commerce talents training in their own attempt, weak situation, the need for professional talents in the talent market to attract, so as to provide support for the sustainable development of tourism electronic commerce and tourism industry development.

The better development of tourism e-commerce needs to highlight its comprehensive service attributes, and the comprehensive service of tourism e-commerce will be better. The positive impact of tourism e-commerce on the development of tourism can be fully realized. The local government should strengthen the guidance of tourism enterprises and tourism enterprises, and build a tourism e-commerce service platform, which makes the tourism information, tourism resources can be better dissemination and contribution in the tourism e-commerce integrated service platform. The comprehensive service of tourism e-commerce also needs the attention of tourism enterprises, and in the case of better service consciousness, tourism e-commerce activities will be carried out. Nowadays, smart phones have become very common. In the era of mobile Internet, it is necessary to become a convenient tool for travel e-commerce. The development of tourism e-commerce can move closer to the mobile APP, to provide services, such as the development of tourist attractions related APP accommodation services, transportation services, we can better promote tourism e-commerce service, which makes the tourism e-commerce better promote the development of the tourism industry.

\section{Summary}

The positive impact of tourism e-commerce on tourism development has been widely recognized, and it is also very feasible to rely on tourism e-commerce for the development of tourism industry, such as new forces. Tourism e-commerce is a relatively new form of e-commerce, and its positive impact on the development of tourism is also affected by many factors. In the new period, promoting the development of tourism e-commerce needs the support of the government and the extensive participation of tourism enterprises, and the development of tourism e-commerce needs better planning. Under the new standard of economic growth, the development of tourism e-commerce will become a new opportunity for the development of domestic tourism, and pay more attention to the comprehensive influence of tourism e-commerce.

\section{References}

[1] Zhang W, Gui-Pei H E. An Empirical Study and Analysis of Residents' Perceptions of Tourism Impact in China's Tourist Destinations[J]. Tourism Tribune, 2008.

[2] Guo X D, Xiao X, Fang L. On the Impact of the New Vacation Policy on the Space-time Structure of China's Domestic Tourism Traffic and Tourism Development[J]. Tourism Tribune, 
2008.

[3] Wang X, Zou T Q. IMPACT OF THE HIGH SPEED NETWORK ON THE DEVELOPMENT AND DISTRIBUTION OF CHINESE AREA'S TOURISM INDUSTRY[J]. Economic Geography, 2010.

[4] Liao K, Hong X U, Yang W, et al. An Empirical Study on the Impact of Golden Week Holiday Institution on the Development of China's Tourism Industry[J]. Tourism Tribune, 2009.

[5] Chen Z X, Chu-Dong Q U. Dynamic Analysis of the Impact of the Opening of Gambling Right on the Economic Efficiency of Gambling and Lottery Tourism Industry in Macau[J]. Tourism Tribune, 2009.

[6] Muro J, Gálvez C S, Sanz M D M Z. The impact of e-commerce on the tourist purchase decision: an empirical analysis[J]. Alcamentos, 2007, 30(9):1135-1157. 